\title{
Fine Structure of Pancreatic Islets of Mice Infected with the M Variant of the Encephalomyocarditis Virus*
}

\author{
K. F. Wellmann, D. Amsterdam, P. Brancato and B.W. Volk \\ Isaac Albert Research Institute of the Kingsbrook Jewish Medical Center, Brooklyn, New York \\ Received: May 12, 1972, accepted: June 22, 1972
}

Summary. Seventy-seven male, 12 to 16 week old CD-1 mice were injected subcutaneously with the M variant of the encephalomyocarditis (EMC) virus. Thirteen saline-injected mice served as controls. The 45 surviving virus-injected mice were sacrificed at intervals ranging from $24 \mathrm{~h}$ to 15 days following injection. Blood glucose values were distinctly elevated during the first 2 days and again between the seventh and fifteenth day of the experiment. Immunoassay of pancreatic tissue revealed a lowering of the mean insulin concentration to one half of that of the control mice. Pancreas suspensions assayed for the presence of virus $2 \frac{1}{2}$ to $9 \frac{1}{2}$ days after infection yielded significant titers as determined by cytopathic effect. No morphologic changes were detected during the first 2 days after virus injection. Thereafter, disruption of islet cell architecture, B cell necrosis, B cell degranulation, and mononuclear cell infiltrates were noted by light microscopy. Ultrastructurally, disruption of nuclear material, dilatation of the perinuclear space, and the appearance of cytoplasmic vesicles filled with fine granular substance were seen in B cells during the early phase of the experiment. Histiocytic response and removal of damaged B cells was prompt. Crystalline viral arrays were not identified. Poor granulation and dilatation of the units of the endoplasmic reticulum were noted in many surviving B cells. Damage to exocrine acinar cells was of limited extent. No salivary gland lesions were identified.

Structure fine des îlots pancréatiques de souris infectées par le variant $M$ du virus de l'encéphalo-myocardite

Résumé. Soixante-dix-sept souris mâles CD-1, âgées de 12 à 16 semaines ont reçu une injection sous-cutanée du variant $\mathbf{M}$ du virus de l'encéphalo-myocardite (EMC). Treize souris recevant une injection d'eau salée, servaient de témoins. Les 45 souris survivantes ayant reçu le virus ont été sacrifiées à des intervalles allant de $24 \mathrm{~h}$ à 15 jours après l'injection. Les valeurs de la glycémie étaient nettement élevées au cours des deux premiers jours et de nouveau entre le septième et le quinzième jour de l'expérience. Le dosage immunologique du tissu pancréatique a révélé une baisse de la concentration moyenne d'insuline de moitié par rapport aux souris témoins. La recherche des virus dans des suspensions de pancréas 2 jours et demi à 9 jours et demi après l'infection a révélé des titres significatifs, déterminés par l'effet cytopathique. On n'a détecté aucune modification morphologique au cours des deux premiers jours après l'injection du virus. Par la suite on a observé au microscope à lumière une rupture de l'architecture des cellules insulaires, une nécrose des cellules $B$, une dégranulation des cellules $B$ et des infiltrats cellulaires mononucléaires. Ultrastructuralement, la rupture du matériel nucléaire, la dilatation de l'espace périnucléaire et l'apparition de vésicules cytoplasmiques remplies de fine substance granulaire ont été vues dans les cellules $B$ au cours de la première phase de l'expérience. La réponse histiocytaire et l'élimination des cellules B lésées étaient rapides. Des formations cristallines de virus n'ont pas été identifiées. Dans plusieurs cellules B survivantes on a noté une faible granulation et une dilatation des unités du réticulum endoplasmique. Les cellules acineuses exocrines présentaient des lésions d'étendue limitée. Aucune lésion des glandes salivaires n'a été identifiée.

Feinstruktur der Langerhansschen Inseln der Maus nach Infektion mit der $M$-Variante des EnzephalomyokarditisVirus

Zusammenfassung. Bei 77 männlichen, 12 bis 16 Wochen alten CD-1-Mäusen wurde subkutan die MVariante des Enzephalomyokarditis-Virus (EMC-Virus) injiziert; 13 Kontrolltiere erhielten NaCl-Lösung statt des Virus. Die 45 überlebenden virus-infizierten Mäuse wurden $24 \mathrm{Std}$ bis 15 Tage später getötet. Die Blutzuckerwerte waren während der ersten zwei Tage sowie vom 7 . bis 15 . Tag des Experiments deutlich erhöht. Die durchschnittliche Insulinkonzentration der Bauchspeicheldrüse sank gegenüber den Kontrollen auf die Hälfte. Virus konnte in den. Bauchspeicheldrüsen $21 / 2$ bis $91 / 2$ Tage nach der Infektion gewebekulturell nachgewiesen werden. Lichtmikroskopiseh wurden in den ersten beiden Tagen keine Veränderungen entdeckt. Danach zeigten sich eine Auflockerung der Inselstruktur mit Nekrose und Degranulierung von B-Zellen sowie mononukleäre Infiltrate. Ultrastrukturell ließen sich zuerst Kernschäden und ein Auftreten von Cytoplasmabläschen mit fein granulierter Substanz in den B-Zellen beobachten. Kurz danach kam es zu einer histiozytären Reaktion mit rascher Beseitigung der geschädigten B-Zellen. Viruskristalle ließen sich nicht nachweisen. Viele überlebende B-Zellen zeigten eine Verminderung der Anzahl der Sekretgranula sowie erweiterte Rüume des endoplasmatischen Reticulum. Die exkretorischen Pankreasanteile wiesen nur geringe, die Kopfspeicheldrüsen keinerlei morphologisch faßbare Schäden auf.

Key words: B cell degranulation, B cell necrosis, encephalomyocarditis virus, histiocytic response, hyperglycaemia, insulin immunoassay, mice, viral infection.
* Supported by Grant A-2203 from the National Institutes of Health. Presented at the 69 th Annual Meeting of the American Association of Pathologists and Bacteriologists, Cincinnati, Ohio, March 12, 1972. 
The $\mathrm{M}$ variant of the encephalomyocarditis (EMC) virus causes lesions in the heart, the brain and the pancreas of infected mice ' $[1,2]$. Damage to the islets of Langerhans is often severe enough to induce a diabetes mellitus-like syndrome [3, 4]. Virologic, physiologic and morphologic changes that characterize this syndrome have recently been recorded by Craighead and Steinke [5] as well as by Müntefering and coworkers [6]. The present communication supplements and extends these observations, especially at the ultrastructural level.

\section{Material and Methods}

A total of 77 male, 12 to 16 week old CD-1 mice, obtained from Charles River Breeding Laboratories, Wilmington, Massachusetts, were utilized. Their weights ranged from 26 to $42 \mathrm{~g}$, with most weights falling between 32 and $38 \mathrm{~g}$. The mice were housed in cages each containing $\mathbf{4}$ animals and were given Purina mouse chow and tap water ad libitum.

We are indebted to Dr. John E. Craighead, Department of Pathology, College of Medicine, University of Vermont, for having been kind enough to supply us with the M variant of the EMIC virus. Virus for subcutaneous injection was assayed prior to inoculation according to a modification of the Takemoto and Liebhaber method [7] utilizing mouse embryo fibroblasts and L-2 cells. Based upon the results of the plaque assay, the virus pool concentrate was diluted to yield 100 plaque-forming units per injectable dose.

Sixty-four mice were injected subcutaneously with $0.1 \mathrm{ml}$ of the suspension containing the virus. A total of 45 animals were sacrificed by cervical dislocation, 3 or 4 each at $1,2,21 / 2,3,3 \frac{1}{2}, 4 \frac{1}{2}, 51 / 2,61 / 2,7,9 \frac{1}{2}$, $11 \frac{1}{2}$ and 15 days after inoculation. The remaining 19 mice expired spontaneously, most between the fourth and fifteenth day of the experiment. Thirteen additional mice served as controls; they were given a subcutaneous dose of $0.1 \mathrm{ml}$ of physiological saline solution, and 1 of the animals was killed on each of the days mentioned for the experimental group.

Blood for glucose determination, carried out by the Nelson-Somogyi method [8], was withdrawn from the heart of each animal at the time of sacrifice. In selected animals, sacrificed $21 / 2$ to $131 / 2$ days after infection, portions of the pancreases were removed aseptically for viral assay. A 10 per cent suspension of the organ in complete medium was prepared, and suspensions were titreed in $\mathrm{L}$ cells grown in plastic trays, using cytopathic effect to determine end points.

The pancreases of all mice were removed immediately and divided into 3 portions. The first and smallest portion of the organ was immersed in cold 1 per cent osmium tetroxide solution with added sucrose [9] and cut into blocks less than $1 \mathrm{~mm}$ long. The blocks were fixed for 90 minutes in ice-cold osmium tetroxide, rinsed briefly in distilled water, dehydrated, and embedded in epoxy resin [10]. Ultra-thin sections were prepared with glass knives on Porter-Blum microtomes. The sections were stained with uranyl acetate and lead citrate [11] and then viewed and photographed with an RCA EMU-3G electron microscope.

The second portion of pancreas was placed in Zenker-formaldehyde solution. Paraffin-embedded sections were cut at 4 micra and stained with hematoxylin and eosin and with a modified aldehyde-fuchsin trichrome stain, as previously described [12].

The third and largest portion of the pancreas, comprising approximately 60 per cent of the total organ mass, was utilized for insulin radio-immunoassay studies employing the two-antibody system of Morgan and Lazarow $[13,14]$ with modifications as recorded [15].

Portions of the salivary glands of all mice were also examined by light and electron microscopy.

\section{BLOOD GLUCOSE AND PANCREATIC INSULIN IN EMC-INFECTED MICE}
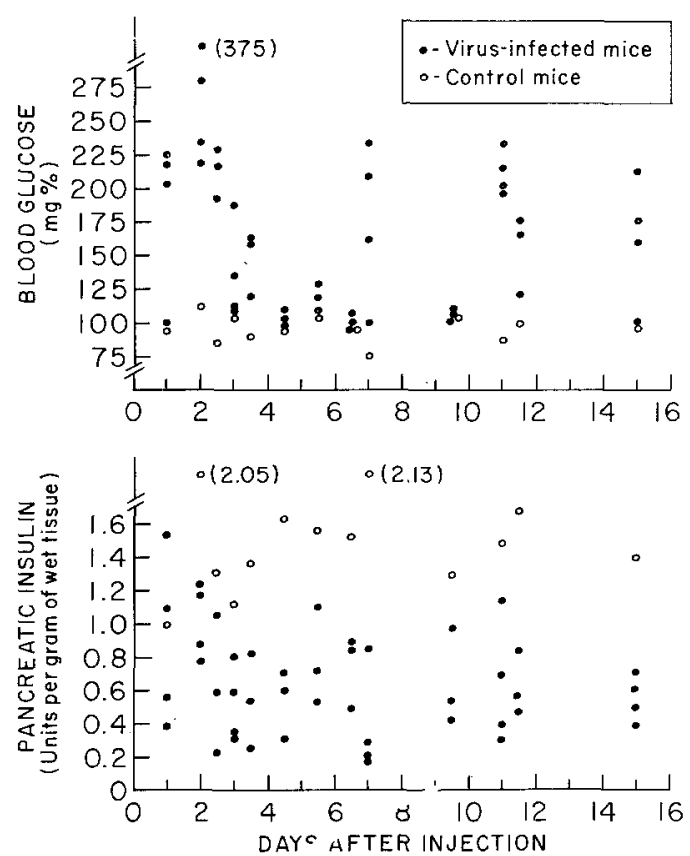

Fig. 1. Blood glucose and pancreatic insulin concentration in EMC-infected mice

\section{Results}

\section{Blood Glucose, Pancreatic Insulin, and Virus Recovery}

The combined averages of the blood glucose values showed a biphasic response, with an early peak of $280 \mathrm{mg}$ per $100 \mathrm{ml}$ on the second day, a return to nearly normal figures over the following days, and a second, less pronounced rise during the second week of the experiment (Fig. 1). Whereas the mean pancreatic insulin concentration of the untreated control mice amounted to 1.53 units per gram of wet tissue, that of 


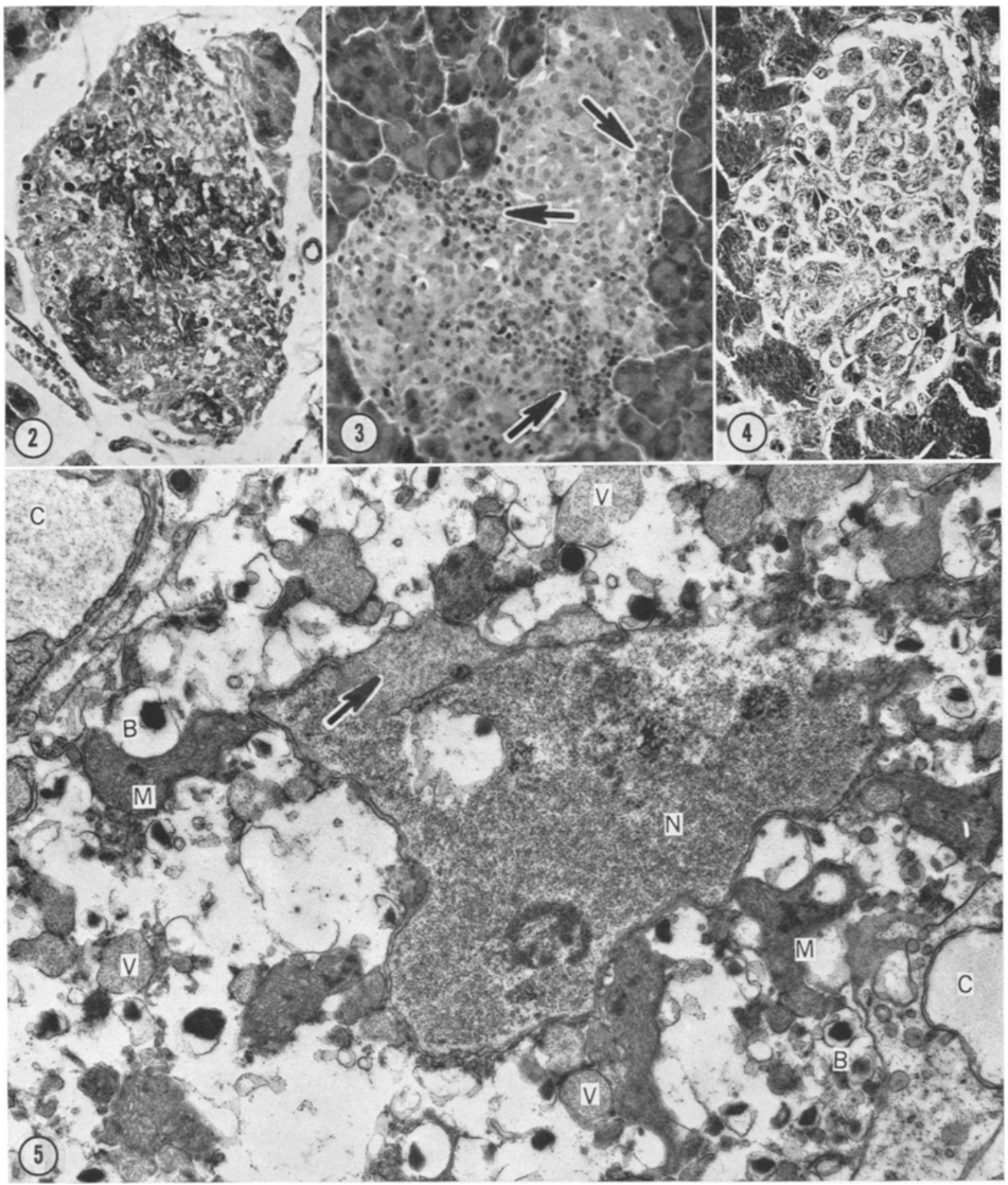

Fig. 2. Islet of Langerhans of mouse 3 days after injection of virus. Degranulation, nuclear pyknosis and disruption of architecture are visible throughout most of the islet. Aldehyde-fuchsin trichrome. $\times 280$. Fig. 3. Small mononuclear cells (arrows) have moved into several parts of this islet, $5 \frac{1}{2}$ days after viral infection of the animal. Hematoxylineosin. $\times 280$. Fig. 4. Small and poorly granulated islet of mouse $11 \frac{1}{2}$ days after EMC virus injection. Aldehydefuchsin trichrome. $\times 375$. Fig. 5. Electron micrograph of pericapillary portion of a pancreatic B cell $21 / 2$ days after virus infection. Cytoplasmic and nuclear disruption are evident. The perinuclear space is focally distended and filled with finely granular material (arrow). Many cytoplasmic vesicles (V), also containing granular substance, are present. B-B cell granules; C-capillaries; M-mitochondria; N-nucleus. $\times 18700$ 


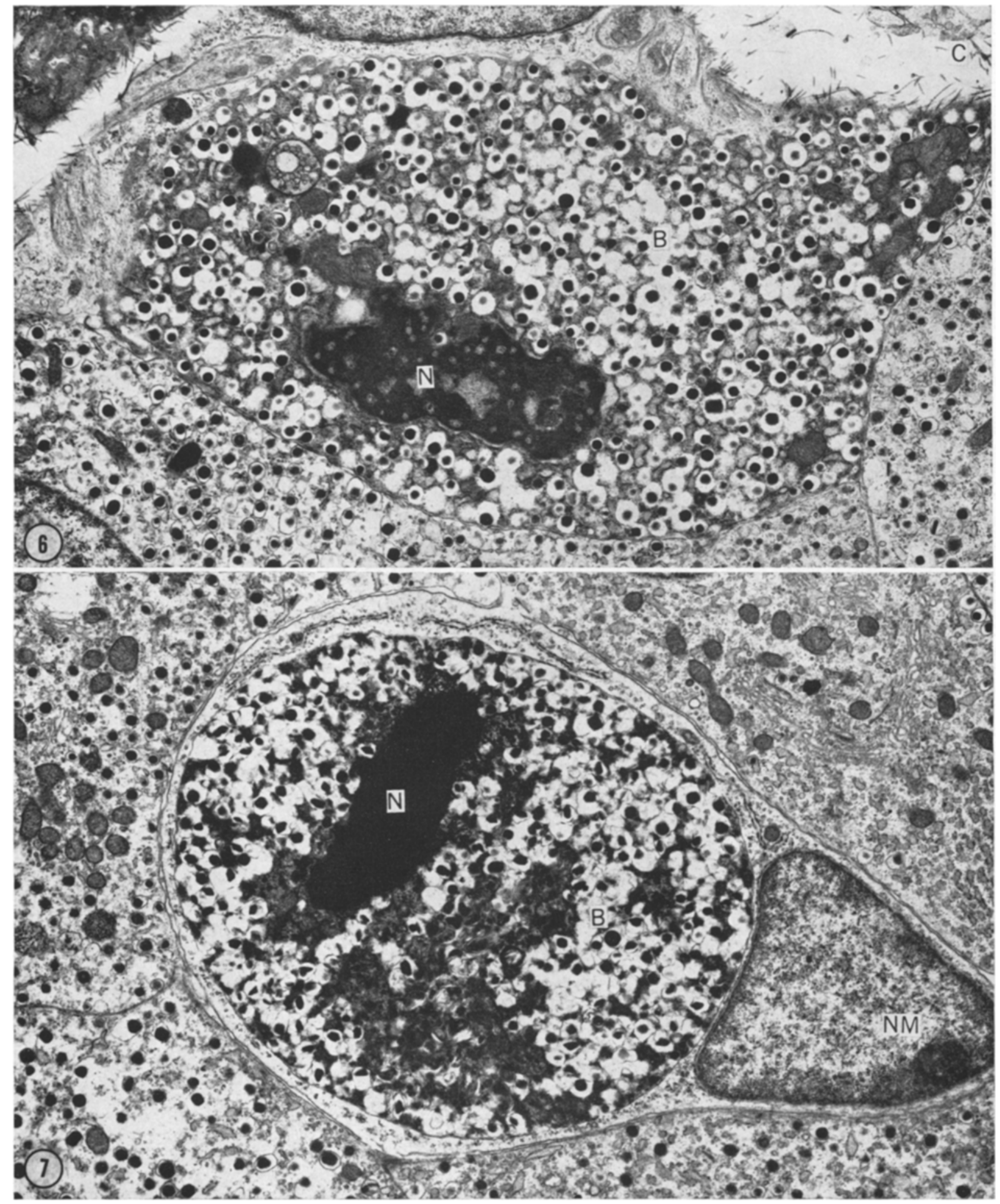

Fig. 6. Damaged B cell (B) at $21 / 2$ days, with pyknotic nucleus (N) and condensed cytoplasm. The surrounding cells are well preserved. C-capillary. $\times 11200$. Fig. 7. Damaged B cell (B), $21 / 2$ days after virus injection, phagocytosed in toto by a macrophage. The surrounding cells appear well preserved. N-pyknotic nucleus of damaged B cell; NMnucleus of macrophage. $\times 10500$ 

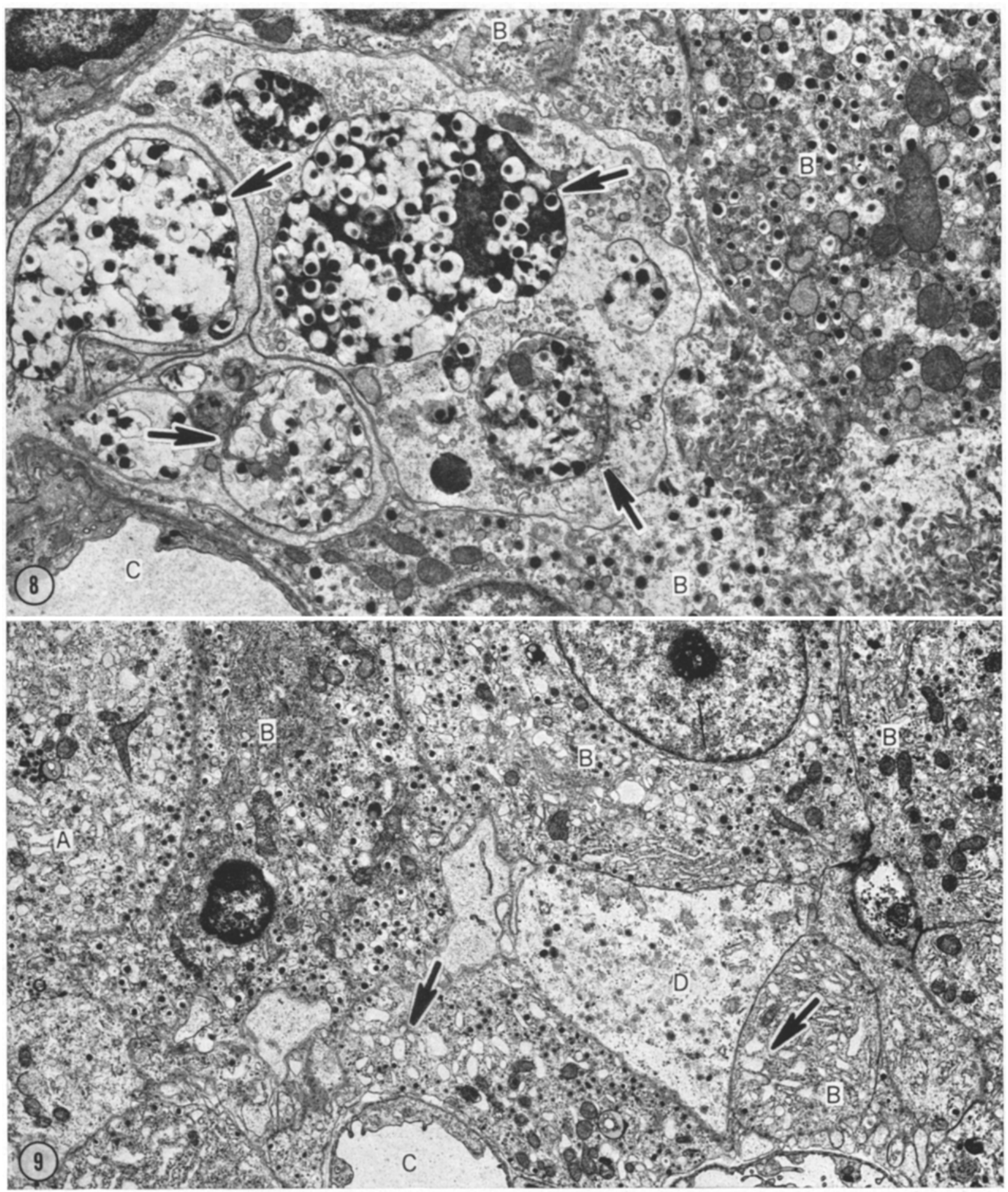

Fig. 8. Pericapillary portion of islet, $2 \frac{1}{2}$ days after viral infection. Several macrophages containing membraneenclosed, phagocytosed fragments of damaged B cells (arrows) have moved in. The surrounding B cells (B) appear well preserved. C-capillary. $\times 10500$. Fig. 9. After $3 \frac{1}{2}$ days, the surviving B cells (B) of this islet appear poorly granulated. The units of the endoplasmic reticulum (arrows) are frequently distended. A-A cell; C-capillary; D-D cell. $\times 6200$ 

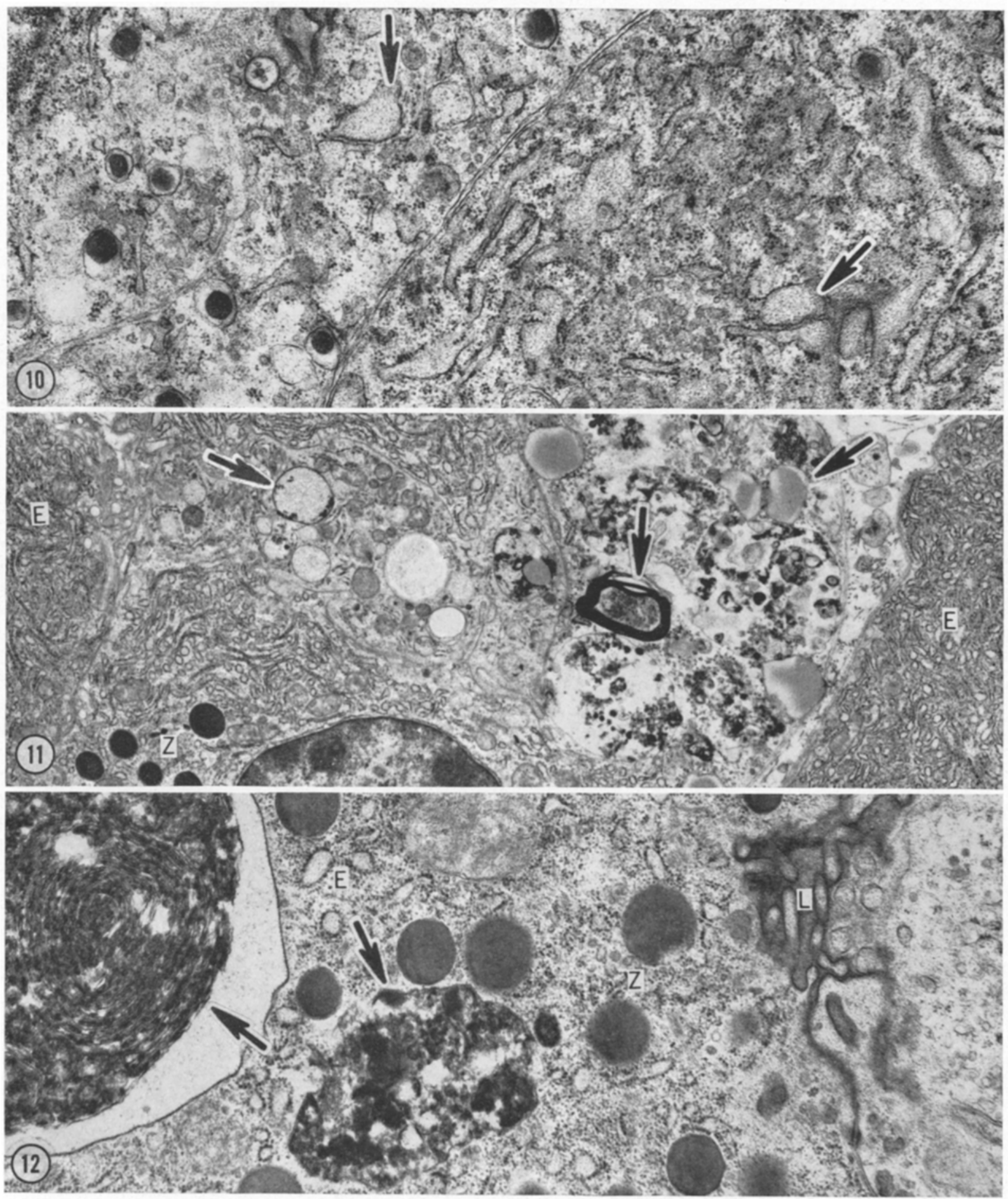

Fig. 10. Portions of rather poorly granulated B cells after $6 \frac{1}{2}$ days. The profiles of the endoplasmic reticulum (arrows) are markedly dilated. $\times 17500$. Fig. 11. Vesicular, membranous and granular inclusions (arrows) are present in the cytoplasm of these exocrine pancreatic acinar cells $3 \frac{1}{2}$ days after virus injection. E-endoplasmic reticulum; Zzymogen granules. $\times 8000$. Fig. 12. Focal cytoplasmic degradation (arrows) in exocrine acinar cell 3 days after viral infection. E-endoplasmic reticulum; L-acinar lumen; Z-zymogen granules. $\times 14000$ 
virus-injected mice was found to be considerably decreased from the first day on and especially so after the third day (Fig. 1)

Virus was recovered from the pancreas in significant titre in all examined animals sacrificed between $21 / 2$ and $91 / 2$ days following injection. After 11 days and more, virus could no longer be recovered.

\section{Light Microscopy}

No light microscopic alterations were noted in the pancreases of mice sacrificed one or two days after the injection of the EMC virus. After $2 \frac{1}{2}$ and 3 days and later, up to the seventh day of the experiment, several but not all islets of most animals showed degranulation of B cells as well as nuclear pyknosis, necrosis of some islet cells, and disruption of the cellular architecture of varying extent (Fig. 2). Somewhat later, small groups of mononuclear cells with reniform or rounded nuclei, presumably histiocytes and lymphocytes, were observed within certain islets or in their immediate vicinity (Fig. 3). In animals sacrificed after more than 7 days, the islets appeared rather small, and necrosis as well as cellular degeneration and mononuclear cell infiltrates were much less evident or were altogether absent. However, the B cells of most mice continued to be poorly granulated to the end of the experimental period (Fig. 4). No remarkable alterations were noted in the islets of the saline-treated controls. There were no definite light microscopic changes in the exocrine portions of the pancreases and in the salivary glands of either virus-injected or control animals.

\section{Electron Microscopy}

There were no ultrastructural alterations in the pancreatic islets of mice sacrificed 1 or 2 days after viral infection. In contrast, all animals killed after $21 / 2$ and 3 days showed pancreatic $B$ cell lesions. First noted were a rarefaction of the eytoplasmic matrix as well as focal disruptions of nuclear material and dilatation of the perinuclear space (Fig. 5). Also present were membrane-enclosed cytoplasmic vesicles filled with finely granular material, and similar substance was seen in distended portions of the perinuclear space (Fig. 5). At the same time, other B cells displayed dark, pyknotic nuclei and considerable condensation of the cytoplasm resulting in crowding of the surviving organelles and of the secretory granules (Fig. 6). Most damaged $B$ cells were quickly phagocytosed by macrophages, either in toto (Fig. 7) or, more often, after their fragmentation (Fig. 8). In all examined islets, $B$ cell destruction was focal or subtotal in extent only; characteristically, damaged B cells usually coexisted side-by-side with well preserved ones (Figs. 6-8).

$B$ cell necrosis and macrophages were less frequently seen after $31 / 2$ and more days and were absent during the later part of the experiment. Instead, the surviving B cells often appeared poorly granulated and exhibited dilated units of the endoplasmic reticulum (Figs. 9 and 10). A and D cells remained free of significant ultrastructural alterations throughout the period of observation.

There were no electron microscopic lesions in the pancreatic islets of the saline-treated control mice.

Most exocrine pancreatic acinar cells and all salivary gland cells failed to display pathologic alterations. However, some of the former showed damage in the form of vesicular, membranous or granular inclusions (Fig. 11) or focal cytoplasmic degradation (Fig. 12), particularly between $21 / 2$ and $51 / 2$ days after viral infection. Frank necrosis was absent, however. Occasional small foci of cytoplasmic degradation were also seen in pancreatic acinar cells of saline-treated controls. The cells of the pancreatic ducts were free of demonstrable lesions.

Attempts to identify virus in the damaged pancreatic cells remained unsuccessful.

\section{Discussion}

The infection of young mice with appropriate doses of EMC virus is followed by hyperglycaemia and marked reduction of the pancreatic insulin concentration (Fig. 1). It is remarkable that both changes are already evident during the first and second day after infection even though the first morphological alterations at the light or electron microscopic level become visible in the pancreas only after the end of the second day. A biphasic blood sugar curve, with the first peak occurring during days 1 and 2, has also been observed by Müntefering et al. [6], whereas Craighead and coworkers [3-5] recorded no blood glucose values before the fourth day after infection. The cause for this initial episode of hyperglycaemia and for the concomitant decrease of pancreatic insulin concentration during days 1 and 2 of the experiment is not readily apparent. Perhaps these early changes are related to nonspecific stress associated with the injection of the virus and the handling of the animals. However, no such alterations were observed in saline-injected control mice.

The lowering of the pancreatic insulin concentrations and of the blood glucose levels between days 2 and 7 (Fig. 1) coincides well with the period of maximal morphologic damage in the pancreatic $B$ cells from which insulin is liberated into the blood stream $[4,5]$. Eventually, the disappearance of many $B$ cells results in the reduction of the diameters of most islets, in the degranulation of the surviving $B$ cells, and in persisting hyperglycaemia as seen in our own material as well as in that of others $[3,5,6]$.

In most islets examined by electron microscopy, $\mathrm{B}$ cell damage was found to be spotty and not massive as, for instance, commonly noted after large doses of alloxan [16]. Characteristically, the B cells were affected singly or in small groups only, and the damaged cells existed side-by-side with others that 
had remained intact (Figs. 6-8). Very striking was the abrupt onset of alterations: at 2 days, none of the islets of any of the examined mice displayed any change whereas numerous damaged $B$ cells were noted in all mice sacrificed only $12 \mathrm{~h}$ later. Also remarkable was the swiftness with which macrophages had moved into the affected islets to phagocytose the dying $B$ cells (Figs. 6 and 7 ); indeed, it proved difficult even at the earliest stage, i.e., $2 \frac{1}{2}$ days after infection, to find damaged $\mathbf{B}$ cells that had not yet been engulfed by macrophages (Fig. 5). In contrast, B cells damaged by alloxan [16] or ischaemia $[6,17]$ may stay around for days before attracting macrophages to the scene. The striking rapidity of the histiocytic response in islets injured by EMC virus is very likely mediated by immune factors; in the serum, hemagglutination inhibition antibody titers against the virus have been shown to rise rapidly after the third day [6], and it has been concluded that the haemagglutinin is the virus protein [18].

Only focal cytoplasmic changes were noted in some of the pancreatic acinar cells $2 \frac{1}{2}$ to $5 \frac{1}{2}$ days after viral infection (Figs. 11 and 12). Whether the virus enters not only the pancreas but also other "zymogen organs" [1] such as the salivary glands remains to be studied. There were no morphologic alterations in the salivary glands of the mice in this experiment.

The first ultrastructural cytopathic changes occurring in L cells infected with the EMC virus [19] consisted of rearrangement and changes in nuclear material followed by a progressive degeneration and dissolution of the nuclei and a distension of the nuclear envelopes. In the cytoplasm of these cells, the formation of numerous vesicles and an increase in the number of ribonucleoprotein particles was observed. Disruption of mitochondria took place at a somewhat later stage. In the heart muscles of infected mice, similar alterations as well as dissolution of myofibrils, sarcoplasmic bleb formation, and crystalline aggregates of virus particles were noted [20]. The early electron microscopic changes in the pancreatic $B$ cells of the mice infected with the $M$ variant of the EMC virus also included focal disruption of nuclear material, dilatation of the perinuclear space, and the appearance of cytoplasmic resicles filled with finely granular substance (Fig. 5). In contrast to the observations in $\mathrm{L}$ cells [19], the nuclei of damaged $\mathrm{B}$ cells did not dissolve but became dense and pyknotic (Figs. 6 and 7). It is possible, however, that the observed morphological alterations beyond the earliest stage were considerably modified by the prompt appearance on the scene of macrophages and the subsequent rapid break-up and phagocytosis of the affected $B$ cells.

We, as well as apparently Müntefering and coworkers [6], were unable to identify by electron microscopy crystalline arrays of virus particles, similar to those described in the myocardium of infected mice $[20,21]$, in the injured $B$ cells even though virus was recovered from pancreatic tissue in significant titres by these and other [5] authors as well as in this laboratory. It is of interest to note that the EMC virus also does not produce crystalline aggregates in cultured. $\mathrm{L}$ cells [19], possibly because the infection enhances the permeability of such cells so that they lyse at an early stage, that is, before protein is coated onto virus RNA within the templates and large pools resulting in the formation of viral crystals $[19,20]$. Crystalline arrays of coxsackie group B virus, an agent classified as picorna-virus as is the organism of encephalomyocarditis, have also been demonstrated in the human heart [22] but not in the pancreases [23] of infected mice.

Acknowledgements. The authors are indebted to Mrs. Celina Mitgang, Mrs. Doris Fok, Mr. Steven Brooks and Mr. Zoran Dordevic for their technical assistance, to Mr. Herbert A. Fischler who prepared the photographs, and to Mrs. Renee Brenner for typing and editing the manuscript.

\section{References}

1. Craighead, J.E.: Pathogenicity of the $\mathbf{M}$ and $\mathbf{E}$ variants of the encephalomyocarditis (EMC) virus. I. Myocardiotropic and neurotropic properties. Amer. J. Path. 48, 333 $\rightarrow 345$ (1966).

2. Craighead, J.E.: Pathogenicity of the M and E variants of the encephalomyocarditis (EMC) virus. II. Lesions of the pancreas, parotid and lacrimal glands. Amer. J. Path. 48, 375-386 (1966).

3. Craighead, J.E., McLane, M.F.: Diabetes mellitus: induction in mice by encephalomyocarditis virus. Science 162, 913-914 (1968).

4. From, G.L.A., Craighead, J.E., McLane, M.F., Steinke, J.: Virus-induced diabetes in mice. Metabolism 17, 1154-1158 (1968).

5. Craighead, J.E., Steinke, J.: Diabetes mellitus-like syndrome in mice infected with encephalomyocarditis virus. Amer. J. Path. 63, 119-134 (1971).

6. Müntefering, H., Schmidt, W.A.K., Körber, W.: Zur Virusgenese des Diabetes mellitus bei der weißen Maus. Dtsch. med. Wschr. 96, 693-697 (1971).

7. Takemoto, K.K., Liebhaber, H. : Virus-polysaccharide interactions. 1. An agar polysaccharide determining plaque morphology of EMC virus. Virology 14, 456462 (1961).

8. Nelson, N.: Photometric adaptation of Somogyi method for determination of glucose. J. Biol. Chem. 153, 375-380 (1944).

9. Caulfield, J.B.: Effects of varying the vehicle for $\mathrm{OsO}^{4}$ in tissue fixation. J. biophys. biochem. Cytol. 3, 827-830 (1957).

10. Luft, J.H.: Improvements in epoxy resin embedding methods. J. biophys. biochem. Cytol. 9, 409-414 (1961).

11. Reynolds, E.S.: The use of lead citrate at high $\mathrm{pH}$ as an electronopaque stain in electron microscopy. J. Cell Biol. 17, 208-212 (1963).

12. Lazarus, S.S., Volk, B.W.: The Pancreas in Human and Experimental Diabetes, pp. 257-267. New York: Grune \& Stratton (1962).

13. Morgan, C.R., Lazarow, A.: Immunoassay of insulin: two antibody system: plasma insulin levels of normal, subdiabetic and diabetic rats. Diabetes 12, 115-126 (1963).

14. Morgan, C.R., Lazarow, A.: Immunoassay of pancreatic and plasma insulin following alloxan injection of rats. Diabetes 14, 669-671 (1965).

15. Volk, B.W., Wellmann, K.F., Lazarus, S.S., Bran- 
cato, P.: Beta cell morphology and insulin immunoassay in long-term subdiabetic rabbits. Arch. Path. 88, $413-422(1969)$

16. Wellmann, K.F., Volk, B.W., Lazarus, S.S.: Ultrastructural pancreatic beta-cell changes in rabbits after small and large doses of alloxan. Diabetes 16, 242$251(1967)$.

17. Schmitz-Moormann, P., Zimmermann, U.: Die Langerhansschen Inseln bei der partiellen permanenten Ischämie des Katzenpankreas. Verh. Dtsch. Ges. Path. 54, $670(1970)$.

18. Faulkner, P., Martin, E.M., Sved, S., Valentine, R.C., Work, T.S.: Studies on protein and nucleic acid metabolism in virus-infected mammalian cells. 2 . The isolation, crystallization and chemical characterization of mouse encephalomyocarditis virus. Biochem. J. 80, 597-605 (1961).

19. Dales, S., Franklin, R.M.: A comparison of the changes in fine structure of $\mathbf{L}$ cells during single cycles of viral multiplication, following their infection with the viruses of Mengo and encephalomyocarditis. J. Cell Biol. 14, 281-302 (1962).
20. Burch, G.E., Harb, J.M., Colcolough, H.L., Tsui, C. Y.: Encephalomyocarditis infection of the newborn mouse myocardium: an electron microscopic study. Arch. intern. Med. 127, 148-156 (1971).

21. Burch, G.E., Tsui, C.Y., Harb, J.M., Colcolough, H.L.: Mural and valvular endocarditis of mice infected with encephalomyocarditis (EMC) virus. Exp. Molec. Path. 14, 327-336(1971).

22. Haas, J.E., Yunis, E.J.: Viral crystalline arrays in human coxsackie myocarditis. Lab. Invest, 23, $442-$ 446 (1970).

23. Burch, G.E., Tsui, C.Y., Harb, J.M., Colcolough, H.L.: Pathologic findings in the pancreas of mice infected with coxsackie-virus B4. Arch. intern. Med. 128, $40-47$ (1971).

Dr. K.F. Wellmann

Clin. Assoc. Prof. of Pathology Isaac Albert Research Institute of the Kingsbrook Jewish Medical Center 86 East 49 th Street

Brooklyn, New York 11203, U.S.A. 